Bochańczyk-Kupka D., The institution of intellectual property rights protection in the face of economic crisis, „Ekonomia i Prawo. Economics and Law”, Polszakiewicz B., Boehlke J. (ed.), Vol. 15, No. 2/2016, pp. 167-177. DOI: http://dx.doi.org/10.12775/EiP.2016.010.

\title{
THE INSTITUTION OF INTELLECTUAL PROPERTY RIGHTS PROTECTION IN THE FACE OF ECONOMIC CRISIS
}

\author{
SUMMARY
}

Nowadays proper protection of intellectual property rights (IPR) is particularly important for strengthening and accelerating economic growth and development. Contemporary society is in transition, from community which wealth is based on tangible assets, to a community which relies mainly on intangible resources. IPR are understood as an institution which guarantees the access to these resources and secures the legal rights of owners. In modern world there are many factors which influence the necessity of stronger IRR protection. Some of them appeared especially during times of economic slowdowns, when the IPR are specially exposed to illegal actions. If the legal system is properly organized and the law is enforced the intellectual property rights seem to be secure. Unfortunately the process of globalization, lack of technical barriers in information flow, decreasing purchasing power of households and poor economic situation of firms operating in competitive environment increase the uncertainty and possibility of illegal actions especially during recession.

The main aim of paper is to identify the channels through which financial crisis affected world economy and intellectual property rights protection. It can be done by describing mutual relationship between the IPR protection and business cycle, mainly phases of recession. The first part of the paper shows the current state of knowledge. Then in the second part the main analyzed economic categories are briefly described.

"Dominika Bochańczyk-Kupka, Katowice University of Economics, Faculty of Economics, Department of Economics, ul. 1 Maja 50, 40-287 Katowice, Poland, phone: + 48322577258 , e-mail: dominika.bochanczyk-kupka@ue.katowice.pl. 
In the last part of the paper the relationship between economic crisis and IPR protection is presented in the context of institutions.

Keywords: economic institutions; economic slowdown; IPR protection JEL Classification: E020; E320; P140

\section{INTRODUCTION}

The crisis of 2008 which unexpectedly hid world economy indicated many problems and contradictions of modern world, especially the weakness of economic and political institutions. The intellectual property rights (IPR) protection is one of the modern institution which has undergone significant changes in recent decades. This slowdown also influenced the role and importance of intellectual property rights protection and contributed to some institutional changes connected with cost of intangible resources protection.

The paper tries to indicate and explain some of relations between intellectual property rights protection and economic crisis. The importance of intellectual property protection can't be overestimated but the optimal level of this protection is still discussed in economic literature. IPR protection as economic institution is a tool which should be used to cope with economic slowdowns. Therefore the indication of relations between these two categories seems to be important and interesting, especially in the context of short-term and longterm economic growth.

\section{THE CURRENT STATE OF KNOWLEDGE AND RESEARCH MEDHOD}

The problem discussed in this paper is not well-known in the economic literature. Most of the studies that cover intellectual property rights protection do not focus on the impact of the crisis. Nevertheless, it might be valuable to describe channels thorough which economic slowdown influence the level of intellectual property rights protection and vice versa. Modern economists present a few, often opposed views. In the modern literature especially opinions of D. Benoliel, M. Gishboliner ${ }^{1}$, S. Chopra, A. Negi²,

${ }^{1}$ D. Benoliel, M. Gishboliner, The Effect Of Economic Crises On Patenting Activity Across Countries, "Journal of Intellectual Property", Vol. 14, No. 2/2015.

2 S. Chopra, A. Negi, Role of Intellectual Property during Recession, "Journal of Intellectual Property Rights" Vol. 15, No. 2/2010. 
K. Lewis ${ }^{3}$ and K.E. Markus ${ }^{4}$ are well-known and widely discussed. The paper tries to show, explain and comment them.

The analysis of the relationship between economic crisis and intellectual property rights protection presented in this paper is based on qualitative information which aim is to gather an in-depth understanding of analyzed impact of economic crisis on intellectual property rights protection and vice versa. The qualitative analysis is the only possible because nowadays there isn't any measure which can be used to show the protection of intellectual property right in long-run ${ }^{5}$. The only available data is related to patents. Therefore the paper tries to examine the phenomenon through some statistical data, mainly connected with patent activity.

\section{ECONOMIC CRISIS, ECONOMIC INSTITUTIONS AND COUNTERFEIT GOODS - DESCRIPTION OF MAIN CATHEGORIES}

\subsection{ECONOMIC CRISIS OF 2007-2008}

The financial crisis hit the global economy in summer of 2008 and was without precedent in post-war economic history. Over the previous decades, the world economy became increasingly integrated owing to the removal of trade barriers, the spread of technology and the liberalization of capital flows. Countries traded much more with one another and international capital markets deepened. World economy grew at a pace unprecedented in recent economic history. The crisis erupted in the financial systems of developed countries quickly affected all economies throughout the world. In 2009, world GDP contracted by $1.1 \%$. The economic slowdown became global in the sense that growth declined was observed in every region of the world in comparison to $2007^{6}$. Economic slowdown resulted in downsizing of national and global

${ }^{3}$ K. Lewis, The Fake and the Fatal: The Consequences of Counterfeits, "The Park Place Economist", Vol. 17/2009.

${ }^{4}$ K.E. Maskus, Intellectual Property Rights And Economic Development. Revised Draft, prepared for the series "Beyond the Treaties: A Symposium on Compliance with International Intellectual Property Law”, organized by Fredrick K.Cox International Law Center at Case Western Reserve University on February 6, 2000.

${ }^{5}$ D. Bochańczyk-Kupka, Ochrona wtasności intelektualnej i jej pomiar - problemy metodologiczne, "Studia Ekonomiczne. Zeszyty Naukowe Uniwersytetu Ekonomicznego w Katowicach", No. 236(2)/2015, pp. 73-84.

${ }^{6}$ E. Gamberoni, E. Uexkull, S. Weber, The Role of Openness and Labour Market Institutions for Employment Dynamics during Economic Crises, "Employment Sector Employment Working Paper", No. 68/2010, p. 1. 
economy, decreasing national and local markets and increasing competition, changes in trade environment, shorter product cycles and changes in $\mathrm{R} \& \mathrm{D}$ investment. In economic literature this crisis's marked by the often unexpected failure of banks, the sharp decrease in credit and trade and the collapse of an exchange rate regime that diminished the efficiency of national economies. Many people lost their jobs, a lot of enterprises went bankrupt and incomes of millions of people were cut. These factors had to influenced the intellectual property rights protection both worldwide and also in national economies ${ }^{7}$.

Economic literature points essential three transmission channels through which financial crisis strongly affected world economy: via the connections within the financial system itself, via wealth and confidence effects on demand and via global trade ${ }^{8}$. This paper focuses mainly on the last two.

Economic crises disturbed normal functions of financial and monetary systems. While economists diverge over the role of the financial sector in economic growth, there is general agreement that economic crises diminishes short-term growth ${ }^{9}$.

\subsection{INTELLECTUAL PROPERTY RIGHTS PROTECTION AS ECONOMIC INSTITUTION}

Nowadays "institution" is a very popular but an ambiguously defined category. Its meaning is not immediately evident and changes according to the context and the academic discipline where its being used. In social sciences, particularly in economics, the most influential theoreticians of the role of institutions have pioneered universal and overarching definitions of them. D. North claimed that institutions were the rules of a game that regularized behavior and social relation and influenced uncertainty reduction and improved the coordination of efforts and economic relations. In other words institutions can be treated as humanly devised constraints that structure political, economic and social interaction. They consist of both informal constraints (sanctions, taboos, customs, traditions, and codes of conduct), and formal rules (constitutions, laws, property rights) ${ }^{10}$. The rules of the game are especially important for two reasons. First, well understood rules establish baseline conditions for human interaction, and give a certain predictability to what other

\footnotetext{
7 Ibidem.

${ }^{8}$ European Commission, Economic Crisis in Europe: Causes, Consequences and Responses, "European Economy", No. 7/2009, p. 36.

${ }^{9}$ World Trade Organization, Trade to Expand by 9.5\% After a Dismal 2009, https://www.wto. org/english/news_e/pres10_e/pr598_e.pdf (15.08.2015).

${ }_{10}$ D.C. North, Institutions, Institutional Change and Economic Performance, Cambridge University Press, Cambridge 1990, p. 97.
} 
will do in a particular context, that permits individual decision making, and multi-party negotiation, to proceed with some degree of certainty. Second, rules can serve to discourage or excluded actions that, if widely practiced, would be economically costly, and encourage actions which, if widely taken, can be productive for $\mathrm{all}^{11}$. There are a lot of different definitions of institution in the economic literature but conclusions are concurrent: institutions explain significant differences in level of incomes among countries ${ }^{12}$.

Intellectual property rights protection as a set formal rules can be treated as institution in economics' sense. It became especially important due to implementation of the Agreement on Trade-Related Aspects of Intellectual Property Rights (TRIPS), concluded under auspices of the World Trade Organization which strengthened global protection regime. The TRIPS Agreement, which came into effect on 1 January 1995, is to date the most comprehensive multilateral agreement on intellectual property and introduced intellectual property rules into the multilateral trading system for the first time $^{13}$.

There is no doubt that nowadays intellectual property right protection which is understood as economic institution influences economic behavior of all economic units and therefore affects the economic activity in short and long-run ${ }^{14}$.

\subsection{COUNTERFEIT GOODS IN ECONOMIC LITERATURE}

According to Trade-Related Aspects on Intellectual Property Rights (TRIPs), counterfeit goods are those that are sold without authorization and

${ }^{11}$ R. Nelson, Technology, Institutions and Economic Growth, Harvard University Press Cambridge 2005, p. 142 and G.M. Hodgson, Recent Developments in Institutional Economics, Edward Elgar, Cheltenham 2003, p. 7.

12 D. Bochańczyk-Kupka, R. Pęciak, Institutions in the context of sustainable development, "The Macrotheme Review", No. 4(5)/2015, pp. 30-45.

13 K.E. Maskus, op. cit.

${ }^{14} \mathrm{It}$ is worth to add that in endogenous growth theory, the protection of intellectual property rights is considered as one of the central institutional requisites to generate long-run technological progress. The mechanism is straight forward and well known: IPR protection through patents secures short-term monopoly profits for successful innovators, and these profits provide the key incentive for private agents to engage in costly and risky R\&D activities. On the other hand it is very difficult to investigate short run relationship between intellectual property rights protection and economic growth because of some delays in economy connected with lack of flexibility (low elasticity) in economic units behavior. 
cannot be distinguished from the trademark-registered goods in various aspects such as design, logo, trademark, and company name ${ }^{15}$.

Counterfeiting is often treated as a social problem as it affects consumer confidence in original products and destroys brand equity. It is also considered an economic problem as it puts a company at risk of future investment in research and development because of unfair competition with counterfeited products present in the market and losses in revenues. The World Intellectual Property Organization (WIPO), which is responsible for the promotion of the protection of intellectual property throughout the world, estimates counterfeiting is costing the global economy more than 100 bln USD a year ${ }^{16}$. According to the World Customs Organization (WCO), whose mission is to improve the administration of customs, pirated and counterfeit goods account for $7-9 \%$ of global trade ${ }^{17}$. Many economists claim that the volume of counterfeit good which are sold each year is underestimated. But even the reported volume of intellectual piracy is significant and has got very negative effect of national economies and international trade. Huge variety and volume of counterfeit and pirated products lead to harmful effect on the economic development due to significant losses of legitimate producers across the globe.

\section{THE RELATIONSHIP BETWEEN INTELLECTUAL PROPERTY PROTECTION AND ECONOMIC CRISIS}

The lower level of income and the fear of revenue lost cause that consumers and firms limit their expenditures and investment (both current and future). Additionally economic units want to keep previous standard of living as long as possible, so they are more likely to cut expenses on branded goods and buy illegal goods as: fakes, counterfeited, unbranded goods. In 2009 the overall amount of cases of detentions by custom decreased in UE from 49381 cases in 2008 to 43572 cases in 2009 and then in 2010 increased sharply to 79112 cases. Number of articles in 2008 amounted 178908 278, then in 2009 this volume decreased to 117959298 and in 2010 accounted for $103306928^{18}$. This data reveals that the scale of piracy in the begin-

15 K. Lewis, op. cit., pp. 47-58 .

${ }^{16}$ K. Idris, Intellectual Property as a Power Tool for Economic Growth, WIPO, Geneva 2003, p. 31.

17 E. M. Kenavy, The Economic Impact Of Counterfeit Goods In Egypt, "International Journal of Business Management \& Research”, Vol. 3, No. 3/2013, pp. 111-128.

18 European Commission, Results at the EU border 2010, http://ec.europa.eu (22.08.2015). 
ning of crisis decreased and then in next years increased sharply. Although the rise in cases to 79112 could be caused by increasing sales via the internet. The growth in on-line sales opened up a new method of distribution for all kinds of intellectual property infringing goods. The European Commission Reports also recorded the shift in type of counterfeit goods being sold. In past infringement of intellectual property rights was mainly related to luxury goods. But since 2009 the share of normal goods in the volume of counterfeit goods has increased constantly ${ }^{19}$. The expansion of Internet and therefore the reduction of transaction costs caused that even counterfeit of normal, not expensive consumer goods gave their producers huge profits. This shift in the types of counterfeit goods is especially interesting and this problem is worth further detailed studies.

Economic literature commonly assumes that during global financial crises private firms consequently tend to retreat to the safety of their domestic markets. It happens because of the lesser familiarity of foreign markets, the currency risk involved in international investment and uncertainties regarding the issue of how states treat foreign assets. During the crisis the willingness to sue competitors increased and therefore in such conditions, a consolidation of patent portfolio may take place. It can influence the fewer patent applications being filed and conversely to more disputes on patent application already filled In Europe last economic crisis caused that numerous industries had to reduce their R\&D budgets and expenditures for the application and maintenance of intellectual property rights.

Also economic crises impacted patenting activity in other way. Economic slowdown reduced patent filling expenditures while hindering quality patenting. There are numerous accounts of a demand increase for patent prosecution discounts over patent filing fees ${ }^{20}$. In the context of the 2008 cri- $^{-}$ sis, the European Union (EU) tried to convince its member states to reduce fees for patent applications and maintenance by up to $75 \%$. Furthermore, the European Commission adopted in 2009 a recommendation to the Council that would provide the Commission with negotiating directives for the conclusion of an agreement creating a Unified Patent Litigation System (UPLS). Such a reduction in legal costs could permit many firms to enforce their patent rights in all EU and European Patent Convention (EPC) countries ${ }^{21}$.

So, the effect of economic crises over patenting activity refers also to institutional dimension. It is connected with the need for patent courts to en-

\footnotetext{
19 Ibidem.

${ }^{20}$ D. Benoliel, M. Gishboliner, op. cit., pp. 316-356.

${ }^{21}$ Ibidem, p. 326.
} 
courage innovation and reduce litigation costs. The economic crisis of 2008 pointed the need for a unitary patent and an integrated patent court to encourage innovation and investment. The European Union has worked for several years on the establishment of a common patent court which will be created on the basis of an international treaty. The negotiations which resulted in the unitary patent can even be traced back to various initiatives dating to the 1970s but works intensified in 2009 during the crisis and in that year three draft documents were published regarding a community patent ${ }^{22}$. Based on those documents, the European Council requested on 6 July 2009 an opinion from the Court of Justice of the European Union. In 2012, EU countries and the European Parliament agreed on the "patent package"23. The agreement which was the second piece of the EU patent package, was signed on 19 February 2013 and will enter into force as soon as 13 states have ratified it. Unitary patent protection will make it possible for inventors (individuals, companies or institutions) to protect their invention in $25 \mathrm{EU}$ countries by submitting a single patent application. After the patent is granted, there will be no need to validate it in each country. Also, the unitary patent protection will make the existing European system simpler and less expensive for inventors and will also protect inventions better than the current system ${ }^{24}$.

In the economic literature also can be found different views on relationship between the crisis and intellectual property protection. T. Veblen in 1906 noticed that society is moving through a transition, from community whose wealth is based on tangible assets, to a community whose wealth depends on intangible resources ${ }^{25}$. Therefore intellectual property rights become extremely important due during economic slowdowns because can give firms a kind of business stability. Times like that encourages innovation, new ideas, methods and intellectual property based activities ${ }^{26}$. In times when money is limited, firms look for alternatives to increase their cash flow and find two

${ }^{22}$ Council regulation on the Community patent, Agreement on the European and Community Patents Court (open to the European Community and all states of the European Patent Convention) and decision to open negotiations regarding this Agreement.

${ }^{23}$ A legislative initiative consisting of two regulations and an international agreement that lay the ground for the creation of unitary patent protection in the EU. The package consists of: a Regulation creating a European patent with unitary effect ("unitary patent"), a Regulation establishing a language regime applicable to the unitary patent and an Agreement between EU countries to set up a single and specialized patent jurisdiction (the "Unified Patent Court").

${ }^{24}$ European Commission, Growth, Internal Market, Industry, Entrepreneurship and SMEs, http://ec.europa.eu (1.09.2015).

${ }_{25}$ T. Veblen, The Place of Science in Modern Civilization, "American Journal of Sociology" Vol. 11, No. 5/1906, pp. 585-609.

${ }^{26}$ S. Chopra, A. Negi, op. cit., pp. 122-129. 
possibilities: product innovation or litigation. Innovations can create new, indispensable products. Through litigation companies try to reinforce their intellectual property rights to protect their product revenues by ensuring their patent positions. In such situation companies can face increasing litigation cost because they protect or defend their products and market positions. The slowing economy usually pushes more and more firms to become strict in protecting their ideas and find ways to expand and generate revenue. A growing number of corporations focus on the strength of their patent portfolio by buying patents from other, often weaker or bankrupt firm.

S. Chopra and A. Neri claim that intellectual property can moderate the impact of economic crisis in three major ways. First, it can serve as a stable asset in times of uncertainty, to continue to serve the purposes of investment and growth when consumer and investor emotions are unpredictable. Second, intellectual property can enable dramatic innovative change in response to the causes of crisis while ensuring the incentives to change remain strong. Third, intellectual property can provide adjustment and adaptation to changing local conditions, by delivering a reason and means by which induced innovation can appear ${ }^{27}$.

Some economists investigate the relation between the national level of development and the importance of intellectual property protection. The influence of economic crisis on intellectual property right protection depends on the national level of development and the importance of multinational enterprises in national economy. The research conducted by D. Benoliel and M. Gishboliner showed that economic crisis reduced the bargaining power of developing countries over intellectual property related goods. They revealed that crisis conditions influence patenting activity in advanced and emerging economies differently. For patent applications by origin where multinational enterprises take central stage this difference can be evident. In such case, annual negative change in GDP in advanced economies is followed by negative change in the count of patent applications, originated from the same country. In emerging economies patent applications by origin are essentially indifferent to changes of GDP. This may indicate that in emerging economies, where innovation is predominantly promoted by multinational corporations patenting activity related decisions come from outside the country. In such cases patenting is substantively less reactive to economic developments within emerging economies themselves.

To sum up, for patent applications count by origin the probability of negative annual change strongly and negatively depends on annual change

${ }^{27}$ Ibidem. 
of GDP, GNIPPP and GERD (respectively for advanced economies) ${ }^{28}$. The obtained by D. Benoliel and M. Gishboliner results indicate the different sources of patenting activity and even innovation in two categories of economies $^{29}$.

\section{CONCLUSIONS}

The crisis which started in 2008 influenced the world economy and it showed the weaknesses of many institutions and the necessity of changes. Intellectual property rights protection is one of great number of economic institutions which create worldwide order. It seems that its role is still underestimated.

Intellectual property rights protection system encourages national intellectual potential and therefore influences economic well-being and economic growth and development. Especially during economic slowdown it can be helpful. An efficient and equitable property right system asserts intangible resources which are crucial for further innovations and therefore development. Intellectual property rights protection is critical to fostering innovation which are necessary to revival of economy. Without protection of ideas, businesses and individuals would not receive the full benefits of their inventions and would focus less on research and development.

The main aim of the paper is the identification and presentation of channels through which financial crisis affects world economy and intellectual property rights protection. Economic literature points three transmission channels through which financial crisis can affect world economy and therefore the intellectual property rights protection: via the connections within the financial system itself, via wealth and confidence effects on demand and via global trade. The paper discusses last two and tries to present different points of view and opinions which are present in the nowadays literature. The paper describes this relations from the point of view of firms and economies, indicates the role of Internet, the impact on international trade and correlation between intellectual property rights and the level of development.

The paper does not cover all problems, just indicates and comments some of them and tries to take part in worldwide discussion about the role of intellectual property rights protection in contemporary world.

${ }^{28}$ GNIPPP (gross national income based on purchasing power parity), GERD (gross domestic expenditure on research and development).

${ }^{29}$ D. Benoliel, M. Gishboliner, op. cit. 


\section{BIBLIOGRAPHY}

Benoliel D., Gishboliner M., The Effect Of Economic Crises On Patenting Activity Across Countries, "Journal of Intellectual Property", Vol. 14, No. 2/2015.

Bochańczyk-Kupka D., Ochrona wtasności intelektualnej i jej pomiar - problemy metodologiczne, "Studia Ekonomiczne. Zeszyty Naukowe Uniwersytetu Ekonomicznego w Katowicach”, No. 236(2)/2015.

Bochańczyk-Kupka D., Pęciak R., Institutions in the context of sustainable development, “The Macrotheme Review”, No. 4(5)/2015.

Chopra S., Negi A., Role of Intellectual Property during Recession, "Journal of Intellectual Property Rights" Vol. 15, No. 2/2010.

European Commission, Economic Crisis in Europe: Causes, Consequences and Responses, “European Economy”, No. 7/2009.

European Commission, Growth, Internal Market, Industry, Entrepreneurship and SMEs, http://ec.europa.eu (1.09.2015).

European Commission, Results at the EU border 2010, http://ec.europa.eu (22.08.2015).

Gamberoni E., Uexkull E., Weber S., The Role of Openness and Labour Market Institutions for Employment Dynamics during Economic Crises, "Employment Sector Employment Working Paper", No. 68/2010.

Hodgson G.M., Recent Developments in Institutional Economics, Edward Elgar, Cheltenham 2003.

Idris K., Intellectual Property as a Power Tool for Economic Growth, WIPO, Geneva 2003.

Kenavy E.M., The Economic Impact Of Counterfeit Goods In Egypt, "International Journal of Business Management \& Research”, Vol. 3, No. 3/2013.

Lewis K., The Fake and the Fatal: The Consequences of Counterfeits, "The Park Place Economist", Vol. 17/2009.

Maskus K.E., Intellectual Property Rights And Economic Development. Revised Draft, prepared for the series "Beyond the Treaties: A Symposium on Compliance with International Intellectual Property Law”, organized by Fredrick K. Cox International Law Center at Case Western Reserve University , February 6, 2000.

Nelson R., Technology, Institutions and Economic Growth, Harvard University Press Cambridge 2005.

North D.C., Institutions, Institutional Change and Economic Performance, Cambridge University Press, Cambridge 1990.

Veblen T., The Place of Science in Modern Civilization, "American Journal of Sociology" Vol. 11, No. 5/1906, http://dx.doi.org/10.1086/211429.

World Trade Organization, Trade to Expand by 9.5\% After a Dismal 2009, https:// www.wto.org/english/news_e/pres10_e/pr598_e.pdf (15.08.2015). 
